\title{
"No Cow Makes This Sort of Profit": Capital, Success, and Maasai Gemstone Traders in Tanzania
}

\author{
Word Count: 8,479
}

\section{Introduction}

In 1967, the gemstone tanzanite was discovered in the Simanjiro district of northern Tanzania in an area called Mererani. Celebrated by gemstone enthusiasts as "the gemstone of the $20^{\text {th }}$ century"(ICA ${ }^{\mathrm{i}}$ 2010-2011) due to its seductive blue-violet hues and rare status, tanzanite quickly rose to popularity and now ranks as one of the top-selling gemstones in the United States (Olson 2008). For the first couple decades after its discovery, tanzanite was mined by artisanal and small-scale miners and the Tanzanian State Mining Corporation (STAMICO) (Schroeder 2010). In the 1990s, under economic liberalization reforms, artisanal and small-scale miners were removed from the core of the mining area, and the South African company, African Gemstone Mining, Ltd. $\left(\right.$ Afgem $^{\mathrm{ii}}$ ) took control over a large portion of land known as "Block C" (Schroeder 2010: 58). Today, Mererani is the bustling epicenter of the tanzanite commodity chain with both large- and small-scale mining operations and an intricate network of people working as miners, trading gemstones, and running small businesses in the only place in the world where tanzanite is mined.

The liberalization of the tanzanite industry in the 1990s created a space for Maasai living in Simanjiro to corner a niche working as middlemen, buying and selling gemstones in Mererani. ${ }^{\text {iii }}$ Although trading gemstones is a relatively new livelihood strategy for Maasai households, like most East African pastoralists, they have diversified their livestock-based production systems for decades by cultivating land, working as guards in urban areas, selling milk, beadwork, and other goods, and working in tourism and conservation (Igoe 2004, May and Ikayo 2007, McCabe et al. 2014, Sachedina and Trench 2009). For many households in Simanjiro, trading tanzanite has become an important livelihood strategy, and it is also rather distinct. In particular, some Maasai men have been able to access and mobilize various forms of capital that have not been attainable in other livelihood pursuits. Moreover, regardless of an individual's success, as a group, tanzanite traders are perceived by others in their home villages to possess new forms of capital that carry societal value because they map onto current ideas about success and what it means to "be Maasai". As a result, the landscape of success in Simanjiro now includes Maasai men who have worked or are currently working as tanzanite traders.

This article provides an ethnographic examination of an understudied but important sector of the mineral commodity chain: mineral trade. In the social sciences, the relationship between mining and livelihoods has received careful scrutiny, as mining activities shape the "social, political, and economic fabric of many societies" (Gilberthorpe and Hilson 2014: 2), and often evoke larger debates concerning poverty and human rights (Bryceson et al. 2014, Hilson 2009, Hilson and Banchirigah 2009, Pegg 2006). Much of the emphasis in the literature has been on the impacts of mining on individuals and groups of people who either live adjacent to large-scale mining operations and are dispossessed from land and resources or who work as miners. Far less attention has been given to the people who participate in mining-related activities further downstream in the commodity chain, but who no less rely on mining as a significant part of a

(C) 2016. This manuscript version is made available under the Elsevier user license

http://www.elsevier.com/open-access/userlicense/1.0/ 
rural livelihood strategy. This article begins to fill this gap by shedding light on an overlooked sector of the mining commodity chain, and examining the ways in which economic, social, and cultural forms of capital articulate with livelihood strategies and changing notions of success among Maasai in Simanjiro. Drawing from ethnographic research conducted over a period of thirteen months in 2008 and 2009 in four Maasai communities and in regular meeting places for tanzanite traders in Simanjiro, I explore the mechanisms through which young, successful tanzanite traders have become agents in reconfiguring social relations and the distribution of power in their home villages. In doing this, I argue that capital accumulation and livelihood change is expressed through a unique cultural style with important implications for power relations in Maasai households and communities. As Maasai tanzanite traders possess, mobilize, and are perceived to embody economic, social and cultural forms of capital, they offer a novel analytical vantage point for gaining new insights into the relationship among mining, livelihoods, capital accumulation, and change within rural communities.

The literature on artisanal and small-scale mining in Tanzania demonstrates the ways in which "capitalist incursions" can impact local representations and positionings in the African context (Hodgson 2011: 5). In a recent edited volume, Deborah Bryceson and her colleagues (2014a) examine the ways in which economic mineralization in Tanzania has "embedded seeds of democracy" in the politics and culture of artisanal and small-scale gold mining communities and regions (Bryceson and Fisher 2014: 201). While the authors pay close attention to the growing tendencies toward democratization, they also highlight the hierarchical structure of gold production and the social and economic disparities embedded in this system (Jønsson and Fold 2009; see also Bryceson and Jønsson 2010, Fisher 2007, Fisher and Mwaipopo 2014, Jønsson and Fold 2009). Adding to the literature that examines the more sinister side of mining and capital accumulation in areas of Sub-Saharan Africa, Bryceson and her colleagues also discuss the ways in which acts and accusations of witchcraft reflect the changing social and economic order of mining (Bryceson et al. 2014b, Duffy 2007, Fraser and Larmer 2010; Smith 2012). This volume fluently captures the local tensions and inequalities that can erupt and intensify in the context of rapid structural change. It suggests that artisanal and small-scale miners are agents in transforming social and economic frontiers.

Like the miners portrayed by Bryceson et al., Maasai tanzanite traders in Simanjiro are actively shaping the economic, social, and political landscapes in their home villages. While tanzanite trading presents an opportunity for young men to earn more money in shorter amounts of time than other livelihood strategies (Smith 2012), an exclusive look at economics paints only a partial picture of the impacts men's involvement in the tanzanite trade is having on communities in Simanjiro. Beyond the economic benefits, tanzanite trading also entails new engagements with social and cultural forms of capital. Successful Maasai tanzanite traders exhibit what James Ferguson identified among urban Zambian Copperbelt workers as "cultural style" or the "practices that signify differences between social categories" [emphasis in original] (1999: 95). Ferguson argues that Copperbelt workers cultivated a viable style over time through a performance that represented the convergence of crosscutting poles of social significance (1999). Among Copperbelt miners, expressions of class crosscut expressions of masculinity. In other words, the working class style of being masculine differed from the upper-class style of being masculine, demonstrating the lack of a "unitary "masculine' mode of behavior" (Ferguson 1999: 95). Successful tanzanite traders appear to be involved in the same process of "self-making" 
(Ferguson 1999: 101), as they accumulate forms of capital that originate from different poles, such as large livestock herds and maintaining international business networks. In doing so, they create a cultural style that is uniquely Maasai yet allows them to fit into a new social category. The ultimate exertion of this difference lies in their ability to access power. To understand the politics of capital among Maasai communities in Simanjiro, it is necessary to first consider the ways in which capital articulates with livestock-based livelihoods.

\section{Herding Livelihoods and Capital}

Among East African pastoralists, livestock have customarily been the most important symbol of wealth, status, and success and therefore have been viewed as the key to quantifying household assets (Grandin 1994, McCabe 2003, Potkanski 1999). It has only been within the last decade or so that social scientists have recognized the significance of livelihood diversification to pastoral households and begun to incorporate non-livestock forms of capital, such as cash from crop sales or off-farm opportunities in quantifications of household wealth. (Homewood et al. 2006, Sachedina and Trench 2009).

There has also been a clearer understanding of the importance of social capital to pastoral households (Galvin 2008, Goldman and Riosmena 2013, McCabe 2004). Social capital, or the casual acquaintances or sanctioned memberships that make up an individual's network ${ }^{\text {iv }}$ (Bebbington and Perreault 1999, Bebbington et al. 2004, Fine 2001, Fox 1996), allows households to reduce risk, buffer change, and maintain their livestock herds (Galvin 2008). During times of hardship, people may borrow livestock from age-mates, neighbors, and clan members, or they may diversify their herds by loaning livestock to others (Salzman 1999). Social networks also allow pastoralists to maintain mobility and access resources, such as grazing land and water, to maintain livestock herds and guarantee livelihood security (Galvin 2008, Goldman and Riosmena 2013, McCabe 2004, Potkanski 1999, Thompson and Homewood 2002). Scholarly examinations of social capital have helped broaden our view of the ways pastoralists manage their livestock assets; however, the importance of social capital to other aspects of pastoralists' lives deserves more attention (deVries et al. 2006, Thompson and Homewood 2002).

In the livelihood literature, very little attention has been given to cultural forms of capital, but cultural capital exists among pastoral communities even though it has not been termed as such. ${ }^{\mathrm{v}}$ Cultural capital includes particular bodies of knowledge, symbols, or behaviors that represent "a more polished, more polite, better policed world" (Bourdieu 1984: 77). Characteristically hegemonic, cultural capital may be embodied, objectified, and institutionalized in ways that serve as markers of status and favor a dominant group (Goldstein 2003). Because livestock traditionally served as the defining feature of pastoral societies both economically and culturally, many rites and traditions involve or revolve around livestock, and people possess cultural capital by having the capacity and knowledge to perform in culturally acceptable ways. For example, a Maasai man gains status by slaughtering the ideal cow_-black with flawless horns - during important ceremonies. In some cases, he might draw from his social networks to find the ideal cow. Showing a mastery of this practice enables belonging and demonstrates that an individual and his household possess cultural knowledge and shrewdness. 
For Maasai, beadwork stands as a key cultural marker and a source of distinction in terms of both livelihood and ethnicity. Corinne Kratz and Donna Pido (2000: 44) describe the relationship between aesthetics and Maasai identity:

From the pastoral Maasai perspective, however, other groups modify the forms and uses of ornament in ways that show their inferiority just as much as their deviance in practice from the pastoral ideal. Indeed, to Maasai the two are interlinked. Aesthetics and expertise in beadwork, pastoral production, and ethnicity are all bound together in the Maasai self-image of domineeringly ideal perfection.

Kratz and Pido suggest that cultural capital sets Maasai apart from other non-herding groups of people. While cultural capital signals belonging, it also indicates difference.

The approach to capital in the literature reinforces the links between pastoral societies and livestock. Indeed, livestock herds continue to play a significant role in Maasai household economies and pastoral identities in Simanjiro. However, in light of the tanzanite trade, new forms of economic, social, and cultural capital are emerging and customary forms of capital are being reconfigured with new meaning. The analysis that follows outlines the ways in which successful tanzanite traders are acquiring, being associated with, and mobilizing economic, social, and cultural forms of capital and discusses the implications of this for Maasai households and communities.

\section{New Configurations of Capital for Maasai in Simanjiro}

"The work at Mererani is a good business. You can build a house, buy a car, a tractor, and livestock. I have never seen a business where you sell such a small thing and make such a big profit. It's incredible; you can buy a gemstone for 50,000 [TZS] and sell for a million. No cow makes this sort of profit."vi Malipe, an elderly man with many children and grandchildren, reflected on the tanzanite trade one afternoon as we sat in his homestead discussing middleman activities at Mererani. Malipe's son David in his late twenties and began trading gemstones in the year 2000. He is one of the few Maasai men in Simanjiro who has achieved such a high level of success.

As Malipe chronicles David's accomplishments, we gaze at David's house built with cement and bricks surrounded by the other houses constructed with stick frames, mud, and dung. Solar panels and a satellite dish on top of David's house shadow the borehole below that supplies the family with a constant, local source of water. Malipe explains:

He [David] built this house, and we can charge our cell phones with the solar power. He bought livestock, which belong to the whole family, and he purchased a tractor, which was used to clear and plow 40 acres for the family. He paid 300,000-400,000 [TZS] to people who are now digging a well for livestock watering. ${ }^{\text {vii }}$ Also he has paid for all of our family's hospital expenses, and he buys livestock medicine. Mererani has helped our family much more than the livestock business. 
In addition, David is married to three wives and owns a motorcycle, a Toyota truck, and has purchased cell phones for many of his family members. Malipe wears his phone around his neck dangling from a beaded necklace.

Malipe's narrative portrays the extent to which cash from gemstone trading has infused a few Maasai households in Simanjiro and is testament to the fact that income from tanzanite trading has the potential to far exceed profits gained from any other livelihood. David stands out as one of the few men who have purchased such costly and conspicuous material items. He is among an even smaller number of men in the ranks of having his own borehole. However, like many of the other tanzanite traders, including those who have been less successful, David has spent a large portion of his income investing in livestock to build up his family's herd and to use as bridewealth for marriage. The common practice of investing in livestock with cash from Mererani shows the enduring economic and symbolic importance of livestock to Maasai households in Simanjiro, as well as the value of livestock as the cornerstone of reciprocal relationships (Goldman 2006).

Sachedina and Trench's (2009) study in Emboreet village of Simanjiro quantitatively demonstrates that men's profits from selling tanzanite are first and foremost invested in livestock. The research presented here echoes these findings; however, a closer look indicates that the shape of these investments is changing, and successful tanzanite traders are playing a major role in reconfiguring herd composition. Customarily, a herd largely comprised of milking cows represented a secure investment in long-term family food security and also indicated the potential for perpetuation of the herd through livestock fertility. Households gained prestige due to their capacity to increase their herds and their ability to lend milking cows out to other households, thereby creating systems of obligation and building social capital (Dahl and Hjort 1976). Recently in Simanjiro, there has been a general shift away from herds largely comprised of milking cows to herds dominated by oxen. People are also diversifying their herds by purchasing new breeds of livestock.

Julius was quite successful trading tanzanite from 1990 to 1992 . Now he only periodically dabbles in the gemstone trade, because he is consumed with other responsibilities in village politics. Julius remarks on the changes he is observing in herd management strategies:

People like to invest in oxen. If someone gets money there [at Mererani] he comes back and buys these because they are worth money. It's really about investment opportunities, things you can sell if your luck fails. But also, they [tanzanite traders] like money and they like to invest in things they can see. They will invest in oxen because they are easily changed to money. A guy will have 100 cows, 60 are oxen because they are worth money, 40 are milking cows; they are not worth so much.

Julius reveals the economic importance of oxen, as well as the ways in which oxen can help build social capital. Oxen represent a form of quick, exchangeable capital (for cash), and widespread cultivation among Maasai in Simanjiro further valorizes oxen as they are often rented or loaned out for use with ox-drawn plows. Cash from tanzanite trading allows some households to invest in livestock for reasons other than purely subsistence, and it is also causing changes in herd composition. 
But successful tanzanite traders are not only investing in livestock, as livestock are no longer perceived to be as secure an investment as they once were. As Malipe, the elder who opened this section explains, "Money is leading, and I believe this is because of the tanzanite trade. People have gone and have gotten a lot of money. Also, the people who have left here have seen lots of changes. They are looking to the future. They would rather have different things like a car. A car cannot die of ECF [East Coast Fever], ${ }^{\text {viii }}$ if you run out of money you can choose to sell it or not run it." Malipe insinuates that investing in a car is less risky than investing in livestock, and he emphasizes the challenges of livestock disease. Social capital is also gained from having a car. A car owner can give rides to people, and a car stands as a conspicuous symbol of wealth. Malipe demonstrates that some tanzanite traders realize and rely on the value of material goods beyond livestock and some are investing in those items with cash from tanzanite trading.

Further illustrating tanzanite traders' discretion in livestock investments is the example of Siti. Siti is an elder who has never been to Mererani and is generally described as being very wealthy. He has eight wives, numerous children, and many livestock. According to several people, he has the most livestock in all of Simanjiro; some report that his herd numbers in the thousands. Most people say that Siti is wealthy because of a family inheritance coupled with effective herd management strategies over the years. However, Siti's wealth is often undermined. His neighbor Mollel complains:

My neighbor [Siti] has thousands of livestock but his homestead looks the poorest. Where he sleeps, what he eats, and what his children wear make him look very poor. Everyone is very busy taking care of livestock and he hasn't sold any livestock. The people in the homestead do lots of work for nothing. He won't sell livestock, build a good house, buy food, clothing, or send his kids to school. I think his heart is poor because he has not given livestock to any relatives. Instead, he only tells you his problems with sickness and hunger.

Mollel's narrative demonstrates how it is not just having livestock, but what one does with livestock that is important. Siti is looked down upon due to how he manages his wealth, and he is often accused of exclusively focusing on livestock production. While Siti has economic capital and the capacity to sell livestock for cash, others perceive him to be lacking the foresight to mobilize his capital. Although livestock are important, it is equally, if not more important to diversify one's assets and means of production. Many successful tanzanite traders use their cash to improve cultivation.

\subsection{Cash and Cultivation}

Cash from the tanzanite trade is not directly contributing to an increase in cultivated acreage (Sachedina and Trench 2009; Smith 2012), but access to cash is indeed changing some of the farming practices in Simanjiro and has potential implications for agricultural productivity. Many households make tradeoffs between keeping livestock and cultivating land. Because of unpredictable rainfall and poor growing soils, the crop yields in this area are generally not enough for people to gain a profit to reinvest in agriculture from year to year. People with little or no income from outside sources must sell livestock to pay for seeds and plowing and usually 
attempt to time these sales when the market price for livestock is high. If the market price for livestock is low, but it is the right time to cultivate, households are forced to sell livestock and will have less money for seeds and plowing. If livestock sales are delayed until the market price increases, households risk missing optimal planting times. This is a common scenario in Simanjiro but is not experienced by everyone.

Malipe does not face these dilemmas, and since David has been working in Mererani, they have not had to sell livestock to purchase seeds. Cash from David's work allows his family to purchase inputs for farming regardless of the market price of livestock. For example, one year their first planting never germinated, and they were able to buy seeds and plant a second time. Malipe's family also hires labor to help with cultivation. Furthermore, they can rent or loan their tractor to assist others with plowing, which can generate income and also build social capital (much like oxen). As Malipe's family demonstrates, cash from the tanzanite trade not only pays for inputs such as seeds, labor, and tractors, but also allows for more flexibility in planting and minimizes some of the risks associated with farming in this region. Malipe's family may also benefit from having more food to eat and a surplus they can sell for a profit. Cash from the tanzanite trade has obvious economic implications for livestock production and cultivation in some households in Simanjiro, but no less important are the social changes that are occurring as a result of men's involvement in the tanzanite trade.

\subsection{Social Capital: Pro-Social Prosperity}

Successful tanzanite traders build social capital through their ability to expand their networks both within and outside of the village. In Mererani, most Maasai men buy and sell gemstones together with a small group or a "mob". Mob membership strengthens existing relationships and expands men's networks outside of the village to Maasai who live elsewhere and may represent different clans. Tanzanite traders also conduct business with people from different ethnic groups and regions of Tanzania, and the most successful tanzanite traders have business networks that span international borders. These relationships transcend age, family, neighbor, clan, and ethnic boundaries that have guided social relations for Maasai in the past (Goldman 2006, Salzman 1999) and can be extremely beneficial by broadening tanzanite traders' connections and granting them access to resources. Only the most successful tanzanite traders mobilize "pro-social prosperity," a type of prosperity identified by James Ferguson as one that builds social capital by providing for or "feeding" people by improving village assets (Ferguson 2006: 73). In Simanjiro, there are health clinics, water pumps, water storage tanks, grinding machines, and schools that have been largely funded by a few successful tanzanite traders. Some tanzanite traders exhibit pro-social prosperity on a smaller scale. For example, some men own tractors with trailers and transport people to and from ceremonies and church; they also haul water for social gatherings.

\subsection{Cultural Capital: Tanzanite Traders’ Distinction}

Economic and social capital are important but are not the only forms of capital tanzanite traders are able to build and mobilize. Tanzanite traders possess cultural capital that is unique to tanzanite trading and Mererani. The most successful tanzanite traders have invested in expensive goods such as cars, motorcycles, and tractors and have built the majority of the brick houses in the area. ${ }^{\mathrm{ix}}$ Some of them have also invested in property elsewhere. One trader owns a home in 
Arusha, as well as a plot of land in a nearby village where he is building guesthouses. Although these material goods are obvious forms of economic capital (and can also be used to build social capital), they also represent unique consumption patterns associated with working at Mererani placing them higher on the social hierarchy of consumers (Bourdieu 1984: 1)

Tanzanite traders also exhibit their distinct taste and build cultural capital through an aesthetic that is exclusive to their trade. Most tanzanite traders continue to wear the customary red garments known as illkarash, for their daily clothing. However, since they have available cash, their clothing is often new, and because they purchase their clothing in Mererani and Arusha, they typically wear ilkarash with different patterns from those worn by people at home. Many tanzanite traders also wear a beige safari vest with multiple pockets over the ilkarash. At the same time tanzanite traders' clothing sets them apart from non-tanzanite-trading Maasai in their home villages, it distinguishes them as Maasai in other contexts. For example, I often observed Maasai tanzanite traders from Simanjiro driving their vehicles around Arusha wearing their ilkarash. In this way, cultural capital in the form of an aesthetic constitutes symbols that serve as a basis for differentiation on several levels. The fact that most tanzanite traders continue to wear the ilkarash signifies how the display of cultural capital also reinforces their identity as Maasai. In addition, tanzanite traders continue to wear the customary beaded jewelry, but the styles are different because of their connection to Mererani. Typically, Maasai men are gifted beaded jewelry made by their girlfriends, lovers, or wives. Tanzanite traders however, are buying jewelry made and sold by Maasai women at Mererani (Smith 2015). Therefore, new styles of beadwork are made at Mererani and then taken back to the villages giving tanzanite traders a distinct look at home.

The most successful tanzanite traders set themselves apart from other Maasai through their Western-style dress. One of the wealthiest and most well known traders in Simanjiro named Kato often wears a button-up shirt, slacks or blue jeans, and sneakers or dress shoes. He wears a thick gold chain around his neck, and like other tanzanite traders, he wears copper rings on each hand. He also wears a beaded bracelet around his wrist - a marker of his Maasai ethnicity (Kratz and Pido 2000). The one time I saw Kato dressed in ilkarash without his gold and copper jewelry was during a ceremony in his home village. The situational character of Kato's self-presentation brings to focus his shrewd ability to fit into two different contexts. He illustrates the importance of knowing when and where to mobilize different forms of capital. Despite his customary attire at the ceremony, however, Kato's cultural (and economic) capital was ever-present. Even though Kato's homestead was located a very short distance from the ceremony, he drove his vehicle (a newer sports utility vehicle) and parked it inside the homestead next to the house where the ceremony was taking place. Throughout the day, the car maintained a conspicuous presence adjacent to the focal point of the ceremonial happenings. While Kato's dress appropriately fit into the milieu of the ceremony, the vehicle stood as a constant reminder of his distinction. In many ways, Kato stands out as an exception due to his incomparable success at tanzanite trading; however, all tanzanite traders possess certain forms of cultural capital due to the simple fact that they work at Mererani. One young man remarked, "Some went [to Mererani] and are not successful, but they keep staying there in order to come back and tell others they are at Mererani." Engaging in the performance of going to Mererani gives men a mark of distinction in their home villages. 
Beyond the performance of going to Mererani, men also become "educated" at Mererani. Many tanzanite traders consider themselves to be more knowledgeable and worldlier than those who stay at home because they are interacting with a global market and learning a new trade. One young tanzanite trader professed, "Those who stay home are ignorant especially in terms of business. They are just people who take care of livestock and know about the forest only. We consider them bush people who don't know much about the big city." At home, tanzanite traders turn their experiences at Mererani into cultural capital by giving others the impression that as a group, they are open-minded, more aware of the world outside their villages, and educated. This process is mediated by shifting notions of success among Maasai in Simanjiro.

\section{Capitals Converge: Shifting Notions of Success}

The most successful tanzanite traders have unequal power and influence in their villages because they have been able to access resources and exhibit behaviors that articulate with contemporary notions of success. In addition, others view tanzanite traders as possessing valuable forms of capital. These processes reflect how ideas about success are socially, materially, and symbolically constructed. Furthermore, these patterns bring to focus the relationship between capital and power in Maasai communities and suggest important connections between livelihoods and cultural identity. Richard Waller (1993: 299) addresses these connections:

Maasai identity has been defined by the successful. Indeed, "Maasainess" may be a projection of that success. But that does not mean that we can ignore the possibility that other views exist and that some of these might come to surface in the future. There may be not a permanent hierarchy of identities, ranging from dominant to suppressed, but instead a wide repertoire from which the community may choose under changing circumstances.

Waller addresses the deep-seated links between pastoral livelihoods and ideologies of success and he also forecasts the potential for cultural identity and notions of success to shift from an exclusive dependence on pastoral production. In 1998, I conducted ethnographic research among Maasai households in the Ngorongoro Conservation Area and Loliondo districts of northern Tanzania. During interviews with household heads, I posed the question, "what does it mean to be successful?" The overwhelming response in both locations was, "many livestock and many children" (Smith 1998). For Maasai, success, or "Maasainess" according to Waller, customarily has been associated with pastoral production. But as Waller suggests, ideas about success are not static. Over a decade after my initial inquiries into what constitutes success, I posed the same question to Maasai households in Simanjiro (Smith 2012). While many people included livestock as a fundamental component of an individual's or a household's success, other material items, such as cars, tractors, and modern houses figured prominently into ideas about success, and now a different emphasis is being placed on children. Ideas of success are also consistently linked to the gemstone trade. In other words, when people discuss success, they reference those who have gained both material possessions and non-material attributes from their work in the tanzanite trade. One man named Paulo stated, "In the past, successful Maasai had livestock. Now this is changing because of Mererani. Successful Maasai now have livestock, cars, and modern houses. They are sending kids to school, have a farm, and have money in the bank. Most of the people who have these things are people who went to Mererani and were successful there. In fact, this 
wouldn't have happened outside of Mererani." Paulo's observation reflects a common perception that success in Simanjiro is directly linked to the tanzanite trade. He primarily addresses the material characteristics of success, but he also eludes to the symbolic features of success, in particular his observation that successful people are sending their children to school.

\subsection{Success and Education}

Education emerges as a fundamental component of people's ideas about success and demonstrates the increasing importance of this type of cultural capital in Simanjiro. ${ }^{\mathrm{x}}$ Children have always been a symbol of status for Maasai, and while children are still important, educating them is even more important. Lasaro, a prominent elder astutely observes, "If you have many children, you can't afford to feed them or send them all to school. It is better to have a small family so you can educate them all." Lasaro suggests a cultural shift away from having many children to educating children. Formal education serves as a means to greater economic opportunities and builds social and cultural capital, by expanding people's networks and legitimizing social difference. Maasai who are formally educated are taught Swahili, the national language, and are enculturated in accordance with national customs and holidays.

Education is also a factor in the diminishing role of children as a promise of livestock for Maasai fathers. Whereas children once assured a man future livestock holdings through bridewealth exchanges, education and the influx of cash have affected this practice. Lasaro explains, "In the past having a lot of children meant you were successful, especially if you had a lot of girls because you received livestock for bridewealth. Now having livestock, a brick house, and money means you are successful. We want daughters to go to school and after school they can get married." Lasaro's ideas about success reflect the importance of education in contemporary notions of success. He also suggests that Maasai identities may no longer be so strictly linked to livestock production. Linguistic representations of success also demonstrate these processes.

\subsection{New Language for New Wealth}

The language people use to describe success reflects changing ideologies of success. The Maa language word orkasis is generally used to describe someone who is successful. It is also used synonymously to refer to someone who is wealthy. My questions to people about success used the term orkasis. Some people answered by separating wealth linguistically and conceptually into two categories. One elder man explains, "Orkasis means having many cows and a big family. Tajiri means having many things such as a house, money, cows, and a car, but few children." "xi Orkasis and tajiri are both used to refer to a successful person, but they imply very distinct types of success and separate people into categories based on different kinds of wealth and the ways in which wealth is obtained. Moreover, these words come from different languages. The use of the word, orkasis from the Maa language implies that wealth is accumulated in a more customary or "Maasai" manner, through large livestock herds and big families. Tajiri, from Swahili, the national language of Tanzania, describes wealth that is also associated with livestock, but less so with family and includes non-cattle material goods. The use of the word tajiri-co-opted from national vernacular — reflects how Maasai ideas about material wealth and success are becoming more grounded in national and even international settings. In Simanjiro, successful tanzanite traders are at the forefront of these changes. 
Sinyok, a very successful tanzanite trader, discusses the difference between orkasis and tajiri:

Orkasis means livestock and kids. Tajiri means livestock, no kids, and having a lot of money. These people are recently successful like those at Mererani. When young people go to Mererani and they don't even have a single wife and they get millions of schillings, they are tajiri. They can buy whatever they want and they may have livestock, cars, money, and houses, but they are too young to have children.

Sinyok goes on to describe how several young men he knows have not married or have only just started their families; these are the ones he says who are quickly becoming wealthy from their work at Mererani. In contrast, Sinyok implies that the type of wealth represented by orkasis is acquired over one's lifetime and is thus characteristic to elders. The value of age and life experience in customary ideas about wealth and success is evidenced by the influence and power male elders generally hold within Maasai society (Hodgson 2001). Now, however, success is linked to new and different forms of capital that tanzanite traders possess, and as young tanzanite traders attain particular goods and qualities associated with changing views of success they are becoming respected and powerful in their own right.

\section{The Power of the Gem: Mobilizing Political Influence}

A vivid example of the structural implications of success can be seen in who is being elected to political positions within the village. The most successful tanzanite traders are overwhelmingly represented in village governments in Simanjiro (McCabe et al. 2014). In the four villages represented in this study, all of the village chairmen have worked at Mererani and the majority $(75 \% ; n=31)$ of the subvillage chairmen have also worked as tanzanite traders. The prevalence of successful tanzanite traders in village governments signals a shift in Maasai ideas about leadership.

Major village decisions have customarily been the responsibility of senior male elders whose status is based on age and gender. However, it has been suggested that the creation of postcolonial village governments has resulted in a scenario where young, formally educated men are now making important village decisions (Goldman 2006, Igoe 2000). In some Maasai-dominated areas, young men who "wield the power of the pen" (Goldman 2006: 121, Hodgson 1999: 145) have been voted into village leadership positions and are therefore able to exert considerable influence over decision-making. These men are respected for their ability to read, write, and speak Swahili, giving them necessary skills to negotiate with others beyond the village setting. In Simanjiro, it appears that the power of the pen has yielded to the power of the gem.

Younger men dominate village governments in Simanjiro. Although only a few of them have attended school, the majority of them have spent time at Mererani, which is often likened to a school. Tobiko, an elder, observes, "Tanzanite traders are involved with politics because Mererani is kind of like a school; they learn how to speak Swahili and hold meetings." As discussed, formal education is valued in Maasai society; however, the skills tanzanite traders gain from working at Mererani are also respected. Tobiko continues, "When people go out there [to Mererani], they become more open minded, meet different people from all over, and learn 
from these people and see different things. Tanzanite traders have seen the world out there. So when they come back they feel they need to show their people what others are doing, and people listen to them." From Tobiko's perspective, newly acquired skills, a broadened awareness of the world, and access to useful information help to prepare men for positions within village governments. Thus, cultural capital in the form of "education" and social capital through the new connections tanzanite traders make contribute to the perception that tanzanite traders have the capacity to perform as village leaders and enable them to gain power.

\section{Conclusion: Cultivating Cultural Style}

This article has examined the different forms of capital successful tanzanite traders access and mobilize through their work at Mererani. Although economic capital is important, social and cultural capital are both equally significant in giving Maasai tanzanite traders an air of distinction and setting them apart from others. As they express a cultural style that is uniquely their own and also maps onto societal ideas about wealth, leadership, and success, Maasai tanzanite traders mobilize capital, gain power, and become agents in shaping the economic, social, and political landscapes of their home communities. These connections among livelihoods, capital, success, and power suggest that tanzanite traders may be motivated to pursue opportunities at Mererani for financial gain and also to improve their status and authority at home. As involvement with resource extraction leads to new forms of material and symbolic wealth, Maasai tanzanite traders demonstrate the ways in which tanzanite traders, a distinct and understudied niche in the gemstone commodity chain, can provide critical insights into the relationship among mining, livelihoods, and change within rural communities.

\footnotetext{
${ }^{\mathrm{i}}$ The International Colored Gemstone Association is a nonprofit arm of the international colored gemstone industry and has over 500 members worldwide.

ii In 2003, Afgem was restructured and renamed TanzaniteOne and transferred its stock listing from South Africa to London's Alternate Investment Market (Schroeder 2010.). In 2010, Tanzania passed a mining law requiring the government to hold an equal share of all new mining projects. When TanzaniteOne's mining license came up for renewal in 2012, they were required to give up half of their equity to STAMICO (Rimoch and Cherng 2013).

iii Maasai men exclusively dominate the tanzanite trade. Very few Maasai women work at Mererani, and those women who do work there sell milk and small wares to the traders and the miners. See Smith 2015 for a discussion of women's work in Mererani.

iv Social capital has been defined in many ways by social scientists. At its most fundamental level, most agree that social capital should be used to refer to social connectedness and networks of relationships to which an agent has ties or is associated with (Bourdieu 1986, Coleman 1988, Portes 1998, Putnam 2001)

${ }^{v}$ Other groups of literature indirectly discuss forms of cultural capital among Maasai. For example, studies of tourism and the politics of indigeneity describe how Maasai have been exploited and have capitalized on their exotic and authentically African image, thereby catering to the cultural tastes of Western tourists (Bruner 1994, 2001).

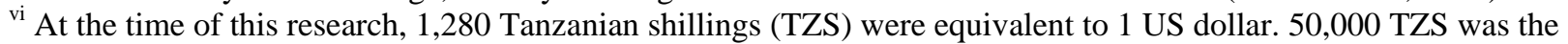
equivalent of approximately 39 US dollars.

${ }^{\text {vii }}$ At the time of this research, 300,000 to 400,000 TZS was approximately 234-312 US dollars.

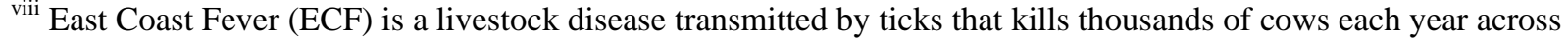
Africa. There is evidence that recently, new vaccines have significantly decreased livestock deaths from ECF (J. Terrence McCabe, personal communication, November 11, 2011).

${ }^{\text {ix }}$ In Simanjiro, there were only four brick houses built and owned by non-tanzanite traders. One belonged to a man who worked for an NGO; a state-level political representative owned another; an expatriate owned one; and the priest of the Catholic Church owned the fourth one.

${ }^{\mathrm{x}}$ Education is important for Maasai in other areas of Tanzania as well (Goldman 2006).
} 
${ }^{x i}$ The TUKI Swahili-English Dictionary (2001: 307) defines tajiri as a rich or wealthy person, a businessperson (man or woman), and an employer. Tajiri, with the same Swahili connotations of wealth and success is also used to refer to dealers of other types of minerals (i.e. gold) in Tanzania (Childs 2014). 


\section{Acknowledgements}

I am extremely grateful for the kindness and openness of Maasai individuals in Simanjiro. I would also like to acknowledge the organizations and individuals who provided funding for this research including the National Science Foundation, the University of Colorado at Boulder Beverly Sears Fund and Anthropology Department, and William and Clare Sheridan. In addition, various individuals provided insight and critique during the writing of this article including, J. Terrence McCabe, Kathleen Galvin, Mara Goldman, Paul Shankman, Carla Jones, Alicia Davis, Colleen Scanlan-Lyons, and Jessica Smith. 


\section{References}

Barth, F., 1961. Nomads of South Persia: The Basseri Tribe of the Khamseh Confederacy. Little, Brown and Company, Boston.

Bebbington, A.J., Perreault T., 1999. Social capital and development in highland Ecuador. Econ. Geogr. 75, 395-418.

Bebbington, A.J., Guggenheim, S., Olson E., Woolcock, M., 2004. Exploring social capital debates at the World Bank. J. of Dev. Stud. 40(5), 33-64.

Bourdieu, P., 1984. Distinction: A Social Critique of the Judgment of Taste. Trans, Richard Nice. Routledge and Kegan Paul Ltd., New York.

Bourdieu, P., 1986. The forms of capital, in: Richardson, J. (Eds.), Handbook of Theory and Research for the Sociology of Education. Greenwood, Connecticut.

Bruner, E.M., 1994. Maasai on the lawn: Tourist realism in East Africa. Cult. Anthr. 9(4), 435470 .

Bruner, E.M., 2001. The Maasai and the Lion King: Authenticity, nationalism, and globalization in African tourism. Am. Ethnol. 28(4), 881-908.

Bryceson, D.F., Fisher, E., 2014. Artisanal mining's democratizing directions and deviations, in: Bryceson, D.F., Fisher, E., Jønsson, J.B., Mwaipopo, R. (Eds.), Mining and Social Transformation in Africa: Mineralizing and Democratizing Trends in Artisanal Production. London, Routledge.

Bryceson, D.F., Fisher, E., Jønsson, J.B., Mwaipopo, R., 2014a. Mining and Social Transformation in Africa: Mineralizing and Democratizing Trends in Artisanal Production. London, Routledge.

Bryceson, D.F., Jønsson, J.B., 2010. Gold digging careers in rural East Africa: Small-scale miners' livelihood choices. World Dev. 38(3), 379-392.

Bryceson, D.F., Jønsson, J.B., Sherrington, R., 2014b. Beyond belief: Mining, magic and murder in Sukumaland, in: Bryceson, D.F., Fisher, E., Jønsson, J.B., Mwaipopo, R. (Eds.), Mining and Social Transformation in Africa: Mineralizing and Democratizing Trends in Artisanal Production. London, Routledge.

Childs, J., 2014. A new means of governing artisanal and small-scale mining? Fairtrade gold and development in Tanzania. Res. Pol. 40, 128-126.

Coleman, J.S., 1988. Social capital in the creation of human capital. The Am. Jour. of Soc. (Supplement: Organizations and Institutions: Sociological and Economic Approaches to the Analysis of Social Structure). 94: S95-S120. 
Dahl, G. and A. Hjort. 1976. Having Herds: Pastoral Herd Growth and Household Economy. Department of Social Anthropology, University of Stockholm, Stockholm.

de Vries, D., Leslie, P.W., McCabe, J. T., 2006. Livestock acquisitions dynamics in nomadic pastoralist herd demography: A case study among Ngisonyoka herders of South Turkana, Kenya. Hum. Ecol. 34(1), 1-25.

Duffy, R., 2007. Gemstone mining in Madagascar: Transnational networks, criminalisation and global integration. Jour. of Mod. Afr. Stud. 45(2), 185-206.

Ferguson, J., 1999. Expectations of Modernity: Myths and Meanings of Urban Life on the Zambian Copperbelt. Berkeley, University of California Press.

Ferguson, J., 2006. Global Shadows: Africa in the Neoliberal World Order. Durham, Duke University Press.

Fine, B., 2001. Social Capital Versus Social Theory: Political Economy and Social Science at the Turn of the Millennium. London, Routledge

Fisher E., 2007. Occupying the margins: Labour integration and social exclusion in artisanal mining in Tanzania. Dev. and Change. 38(4), 735-760.

Fisher E., Mwaipopo, R., 2014. The creativity of action: Property, kin and the social in African artisanal mining, in: Bryceson, D.F., Fisher, E., Jonsson, J.B., Mwaipopo, R., (Eds.) Mining and Social Transformation in Africa: Mineralizing and Democratizing Trends in Artisanal Production. London, Routledge.

Fox, J., 1996. How does civil society thicken? The political construction of social capital in rural Mexico. World Dev. 24(6), 1089-1103.

Fraser, A., Larmer, M., 2010. Zambian Mining and Neoliberalism: Boom and Bust on the Globalized Copperbelt. New York, Palgrave Macmillan.

Fratkin, E., 1989. Household variation and gender inequality in Ariaal pastoral production: Results of a stratified time-allocation survey. Am. Anthro. 91, 430-440.

Fratkin, E., 1998. Ariaal Pastoralists of Kenya: Surviving Drought and Development in Africa's Arid Lands. Boston, Allyn and Bacon.

Fratkin E., Roth, E.A. 1990. Drought and economic differentiation among Ariaal pastoralists of Kenya. Hum. Ecol. 18(4), 385-402.

Galaty, J., 1982. Being "Maasai"; Being "People-of-Cattle": Ethnic shifters in East Africa. Am. Ethnol. 9(1), 1-20. 
Galvin, K.A., 2008. Responses of pastoralists to land fragmentation: Social capital, connectivity, and resilience, in: Galvin, K. A., Reid, R.S., Behnke, R.H., Hobbs, N.T. (Eds.) Fragmentation in Semi-Arid and Arid Landscapes: Consequences for Human and Natural Systems. Dordrecht, Springer, pp. 369-390.

Gilberthorpe and Hilson, 2014. Introduction, in: Gilberthorpe, E., Hilson, G. (Eds.) Natural Resource Extraction and Indigenous Livelihoods: Development Challenges in an Era of Globalization. England, Ashgate, pp. 1-10.

Goldman, M., 2006. Sharing Pastures, Building Dialogues: Maasai and Wildlife Conservation in Northern Tanzania. Unpublished PhD Thesis. University of Wisconsin, Madison.

Goldman, M.J., Riosmena F., 2013. Adaptive capacity and vulnerability to drought in Tanzanian Maasailand: Changing strategies to navigate across fragmented landscapes. Glob. Environ. Change. 23(3), 588-597.

Goldstein, D.M., 2003. Laughter Out of Place: Race, Class, Violence, and Sexuality in a Rio Shantytown. Berkeley, University of California Press.

Grandin, B.E., 1994. Wealth ranking, in: Feldstein, H.S., Jiggins J. (Eds.). Tools for the field: Methodologies handbook for gender analysis in agriculture. Hartford, Kumarian Press, pp. 2135 .

Grandin, B.E., 1988. Wealth and pastoral dairy production: A case study from Maasailand. Hum. Ecol. 16(1), 1-21.

Hilson, G., 2009. Small-scale mining, poverty and economic development in sub-Saharan Africa: An overview. Res. Pol. 34(1-2), 1-5

Hilson G., Banchirigah S., 2009. Are alternative livelihood projects alleviating poverty in mining communities? Experiences from Ghana. Jour. of Dev. Stud. 45(2):172-196.

doi:10.1080/00220380802553057.

Hodgson, D., 1999. Once intrepid warriors: Modernity and the production of Maasai masculinities. Ethnol. 38(2), 121-150.

Hodgson, D. 2001. Once Intrepid Warriors: Gender, Ethnicity, and the Cultural Politics of Maasai Development. Bloomington: Indiana University Press.

Hodgon, D., 2011. Being Maasai, Becoming Indigenous: Postcolonial Politics in a Neoliberal World. Bloomington, Indiana University Press.

Homewood, K., Coast, E., Kiruswa, S., Serneels S., Thompson, M., Trench P., 2006. Maasai pastoralists: Diversification and poverty. London School of Economics Research Online. Retrieved May 1, 2010, from http://eprints.lse.ac.uk/archive/00000821 
ICA (International Colored Gemstone Association). 2010-2011. Tanzanite. URL:

http://www.gemstone.org/gem-by-gem/english/tanzanite.html (accessed February 16, 2010).

Igoe, J., 2000. Ethnicity, civil society, and the Tanzanian pastoralist NGO movement: The continuities and discontinuities of liberalized development. Unpublished PhD Thesis. Boston, Boston University.

Igoe, J., 2004. Conservation and Globalization: A Study of National Parks and Indigenous Communities from East Africa to South Dakota. Toronto, Thomson Wadsworth.

Jønsson J.B., Fold, N., 2009. Rushing for gold: Mobility and artisanal mining in East Africa. Nat. Res. For. 33(3), 211-220.

Jønsson J.B., Fold, N., 2014 Dealing with ambiguity: Policy and practice among artisanal gold miners, in: Bryceson, D.F., Fisher, E., Jønsson, J.B., Mwaipopo, R. (Eds.), Mining and Social Transformation in Africa: Mineralizing and Democratizing Trends in Artisanal Production. London, Routledge.

Kratz, C., Pido, D., 2000. Gender, ethnicity and social aesthetics in Maasai and Okiek beadwork, in: Hodgson, D.L., (Ed.). Rethinking Pastoralism in Africa: Gender, Culture and the Myth of the Patriarchal Pastoralist. London, James Currey, pp. 43-71.

May, A., Ole Ikayo F.N., 2007. Wearing Illkarash: Narratives of image, identity and change among Maasai labour migrants in Tanzania. Dev. and Change 38(2), 275-298.

McCabe, J.T., 2003. Sustainability and livelihood diversification among the Maasai of northern Tanzania. Hum. Organ. 62(2), 100-111.

McCabe, J., 2004. Cattle Bring Us To Our Enemies: Turkana Ecology, Politics, and Raiding in a Disequilibrium System. Ann Arbor, University of Michigan Press.

McCabe, J.T., Smith, N.M., Leslie, P.W., Telligman, A.L., 2014. Livelihood diversification through migration among a pastoral people: Contrasting case studies of Maasai in northern Tanzania. Hum. Organ. 73(4), 389-400.

Olson, D.W., 2008. 2006 Minerals Yearbook: Gemstones. Reston, VA, U.S. Geological Survey.

Pegg, S., 2006. Mining and poverty reduction: Transforming rhetoric into reality. Jour. of Clean. Prod. 14(3-4), 376-387.

Portes, A., 1998. Social capital: It's origins and application in modern sociology. Ann. Rev, of Soc. 24, 1-24.

Potkanski, T., 1999. Mutual assistance among the Ngorongoro Maasai, in: Anderson, D.M., Broch-Due, V, (Eds.). The Poor Are Not Us: Poverty and Pastoralism in Eastern Africa. Oxford, James Currey, pp.199-218. 
Rimoch D., Cherng, S., 2013. A rare and beautiful stone fails to shine: Tanzania's missed opportunity. Knowledge@ Wharton at The University of Pennsylvania.

http://knowledge.wharton.upenn.edu/article/rare-beautiful-stone-fails-shine-tanzanias-missedopportunity/

Sachedina, H., Trench P.C., 2009. Cattle and crops, tourism and tanzanite: Poverty, land-use change and conservation in Simanjiro District, Tanzania, in: Homewood, K., Kristjanson, P., Trench, P.C., (Eds.). Staying Maasai?: Livelihoods, Conservation and Development in East African Rangelands. New York, Springer, pp. 263-298.

Salzman, P.C., 1999. Is inequality universal? Curr. Anthro. 40(1), 31-61.

Schroeder, R., 2010. Tanzanite as conflict gem: Certifying a secure commodity chain in Tanzania. Geoforum. 41, 56-65.

Smith, N.M., 1999. Maasai household economy: A Comparison between the Loliondo Game Controlled Area and the Ngorongoro Conservation Area, northern Tanzania. Unpublished Master's Thesis. Colorado State University, Fort Collins.

Smith, N.M., 2012. Maasai and the Tanzanite Trade: New Facets of Livelihood Diversification in Northern Tanzania. Unpublished PhD Thesis. University of Colorado, Boulder.

Smith N.M., 2015. Gender and livelihood diversification: Maasai women's market activities in northern Tanzania. Jour. of Dev. Stud. 51(3), 305-318. DOI: 10.1080/00220388.2014.957278

Thompson, M., Homewood, K., 2002. Entrepreneurs, elites, and exclusion in Maasailand: Trends in wildlife conservation and pastoral development. Hum. Ecol. 30(1), 107-138.

Tuki Kamusi Ya Kiswahili-Kingereza Swahili-English Dictionary. 1st ed. 2001. Dar es Salaam, Chuo Kikuu Cha Dar es Salaam.

Waller, R., 1993. Conclusions, in: Spear, T., Waller, R., (Eds.). Being Maasai: Ethnicity and Identity in East Africa. London, James Currey, pp. 290-302. 